FACTA UNIVERSITATIS

Series: Linguistics and Literature Vol. 18, No 2, 2020, pp. 159-179

https://doi.org/10.22190/FULL2002159F

Original Scientific Paper

\title{
TESTING THE ACTIVATION OF SEMANTIC FRAMES IN A LEXICAL DECISION TASK AND A CATEGORIZATION TASK*
}

\author{
UDC 81'37
}

\author{
Vladimir Figar \\ English Department, Faculty of Philosophy, University of Niš, Serbia \\ Language Cognition Lab, Faculty of Philosophy, University of Niš, Serbia \\ Center for Cognitive Sciences, University of Niš, Serbia
}

\begin{abstract}
Situated in the wider framework of frame semantics, the paper employs an experimental approach involving a reaction time study to test the activation of semantic frames via semantic priming. Experiment 1 deals with the frame of JOURNEY and employs a lexical decision task in a reaction time paradigm, while Experiment 2 deals with the frame of CONFLICT and uses a categorization task, also in a reaction time paradigm. Both experiments were designed in Open Sesame. Target stimuli were in Serbian, selected through a norming procedure involving prototypicality ratings on Likert scales. Additionally, identical filler items were included in both experiments. Priming was performed using lexical materials modified to facilitate the activation of the respective frames. The obtained results showed that there was no facilitation in the experimental group in Experiment 1 compared to the control group; however, in Experiment 2, we were able to identify facilitation in the experimental group in the main task, licensed by the initial priming. These results suggest that the lexical decision task has a reduced cognitive load compared to the categorization task, thereby overriding the priming condition. In effect, categorization task appears to be a more suitable procedure for testing semantic frame activation.
\end{abstract}

Key words: semantic frames, lexical decision, categorization, reaction times, priming, Open Sesame.

\section{INTRODUCTION}

The paper explores possible methodological constraints in captivating the activation of semantic frames in an RT paradigm using lexical decision and categorization tasks. In line with the encyclopedic view of meaning, where semantic content should yield access to

\footnotetext{
Submitted August 8th, 2020; Accepted December 12, 2020

Corresponding author: Vladimir Figar

University of Niš, Faculty of Philosophy

E-mail: vladimir.figar.81@gmail.com

* Prepared as a part of the project Innovations in the Teaching Process and Research in the Domains of English Linguistics and Anglo-American Literature and Culture, conducted at the University of Niš - Faculty of Philosophy (No. 360/1-16-1-01).

(C) 2020 by University of Niš, Serbia | Creative Commons Licence: CC BY-NC-ND
} 
larger meaning structures, i.e. frames, related to the initial content (e.g. Fillmore 1982; 1985; Evans 2009), we hypothesized that the pre-task presentation of semantic content (i.e. semantic priming) would facilitate participants' RTs to targets semantically related to priming materials, in both lexical decision and categorization tasks in the two main experiments.

The paper deals with the frames of JOURNEY and CONFLICT. In Experiment 1, participants from the experimental group were first instructed to read a paragraph ${ }^{1}$ designed to activate the frame of JOURNEY, after which they proceeded to the lexical decision task with targets from the JOURNEY frame. All targets had undergone an initial norming procedure and were then chosen based on their prototypicality ratings. The control group proceeded to the main task, without priming. Experiment 2 utilized a similar experimental setup, but it dealt with the frame of CONFLICT, and it involved a categorization task. All targets had also undergone initial norming. Priming materials were taken from literary texts, and were modified in order to yield the activation of each of the two target frames, respectively.

\section{THEORETICAL FRAMEWORK}

The enterprise of frame semantics, which encapsulates the notion of the encyclopedic view of meaning, stems from Charles Fillmore's work in the more formal domain dealing with the description of verb valence. Namely, Fillmore realized that a comprehensive description of verb 'behavior' would necessitate a schematic description of scenes and contexts in which they are used (Fillmore 1969). The traditional notion of a static, rigid, structuralist construct of a semantic field was replaced by a more flexible construct of a frame (Fillmore 1975). Moreover, the subsequent stages in the development of frame semantics attributed even greater significance to the notions of context, frame, and prototype. These involved the initial model of case frames (Fillmore 1968) and scene-and-frame model (Fillmore 1975), through the dynamic model of semantics of understanding (Fillmore 1985), to the construction of the FrameNet research program (Fillmore and Atkins 1992).

In his most cited article, Fillmore $(1982,111)$ defined frames as "any system of concepts related in such a way that to understand any one of them you have to understand the whole structure in which it fits; when one of the things in such a structure is introduced into a text, or into a conversation, all of the others are automatically made available." In other words, frames can be understood as highly schematic, hierarchically organized structures with clear prototypicality effects (Fillmore 1976, 25), where the presence of one lexical element from a given frame yields the activation of the entire structure, which makes it more accessible for online processing compared to some other incongruent structures. Moreover, entire frame structures can show prototypicality effects (Fillmore $1982,119)$, in the sense that certain framing may be more common and more prototypical under certain conditions (i.e. in various contexts of use). A distinction is also made between (i) evoked frames, triggered by the text content, and (ii) invoked frames, activated by the readers. Namely, individual lexical items are expected to afford access to specific frames. During online meaning construction, on the other hand, interlocutors activate frame-level structures, and the finer nuances of the activated content can differ between speakers (Croft and Cruse 2004, 8).

\footnotetext{
${ }^{1}$ All materials used in the study were in Serbian, in line with the main methodological guidelines (e.g. Kostić 2010) where, unless the research is dealing with language acqusition or foreign language learning, all stimuli should be represented in participants' mother tongue - in our case in Serbian.
} 
Additionally, Fillmore $(1982,130)$ also brings together the ideas of framing and contextualization, insofar as the "general concept of "framing' involves contextualizing or situating events in the broadest sense possible." In the the present study, notions of framing and contextualization are closely related to the notion of semantic priming. Semantic priming entails "the improvement in speed or accuracy to respond to a stimulus, such as a word or a picture, when it is preceded by a semantically related stimulus (e.g., cat-dog) relative to when it is preceded by a semantically unrelated stimulus (e.g., table-dog)" (McNamara 2005, 3-4). In that sense, specific framings of events (i.e. specific semantic priming) should afford quicker access to elements congruent with the activated frame. Bearing in mind that some typical tasks involved in experiments with a semantic priming paradigm include lexical decision, naming (or pronunciation), and semantic categorization (McNamara 2005, 3-4), the present study will compare the efficacy of lexical decision and categorization tasks in capturing the level of activation of specific semantic frames.

Another important theoretical construct for the present research is categorization. Building on the notion of the probabilistic degree of category membership afforded by the fuzzy boundaries of categories (Lakoff 1973; Zadeh 1965), Rosch introduced the notions of basic level (e.g. Rosch et al. 1976) and family resemblances (e.g. Rosch and Mervis 1975). Family resemblances reflect the horizontal axis of categorization which "represents contrasting categories which are included in the next highest category" (Taylor 1995, 46). The basic level reflects the vertical axis and it is defined as "the most inclusive level [of categorization] at which there is a cluster of shared attributes" (Evans and Green 2006, 258). Moreover, basic level categories appear as "our earliest and most natural form of categorization" (Lakoff 1987, 49). In addition to common categories, Barsalou (Barsalou $1983,211)$ introduced the notion of ad hoc categories which are "created spontaneously for use in specialized contexts."

The present paper utilizes the notion of the central prototype, used in the two norming studies to select the target stimuli for the two main experiments. We feel that the selection of more central elements will facilitate the online construction of the link between the semantic frame, presumably activated in the priming procedure, and the salient targets selected for the main task.

\section{PREVIOUS PSYCHOLINGUISTIC RESEARCH}

Meyer and Ellis (1970) conducted a study which involved a lexical decision task and a categorization task. They also took into account the level of inclusiveness, i.e. category size, where the smaller target category was that of BUILDINGS, and the larger one that of STRUCTURES. As targets, the authors included congruent and incongruent words, and also pseudowords based on existing English words in which at least one vowel was replaced with a different vowel, or a consonant with another consonant. The dependent variables of interest were response latencies "measured from the onset of the test stimulus" (Meyer and Ellis 1970, 4), and response accuracy. Moreover, the data for yes/no responses were analyzed separately.

The obtained results showed that participants were faster in giving 'yes' responses compared to 'no' responses, and the mean RT increased "with semantic category size for both responses, although the category-size effect was somewhat less for yes responses" (Meyer and Ellis 1970,4). Mean RTs recorded in the lexical decision task "fell between those of yes answers to the semantic questions" (Meyer and Ellis 1970,4). The authors attributed the results to the 
fact that a larger category size entails a larger number of possible search items, and that the categorization task and lexical decision task involve different underlying processes.

Meyer and Schvaneveldt (1971) conducted a study which explored the effects of meaning on RTs in a lexical decision task. Participants were presented with two strings of letters, one above the other. In the first experiment, they were asked to provide a "yes" response if they encountered a pair of words or a "no" response in all other cases. In the second experiment, participants were asked to respond as "same" if both strings were either words or nonwords, or "different" in all other cases. RTs were understood to reflect the degree of the associative link between the two given words, and the two experimental tasks were designed to investigate "the nature and the invariance of underlying retrieval operations" (Meyer and Schvaneveldt 1971, 229).

The first experiment showed that the degree of association between words poses as a much more powerful factor compared to the effects of homography analyzed in previous studies (Meyer and Schvaneveldt 1971: 229). Comparisons of RTs from the two experiments revealed the following findings: (i) "yes" responses in case of pairs of words were faster than "same" responses to the same combination of stimuli; (ii) "no" responses were faster than "different" responses for the same combinations of stimuli; (iii) the difference in the effect of association between "yes' and "same" responses for pairs of words did not reach significance; and (iv) the effect of word position for word/nonword pairs on RT showed significant interaction with the type of the task (Meyer and Schvaneveldt 1971, 229). Meyer and Schvaneveldt $(1971,233)$ discussed the potential relevance of the obtained data for some of the dominant processing models (spreading excitation, location shifting, comparison of meanings, and serial decision model), and concluded that "the effects of associations appear limited neither to semantic nor to same-different judgements."

Higgins, Bargh and Lombardi (1985) explored the effects of priming on a subsequent categorization task. The subjects were asked to perform a categorization task after being primed by the target content which appeared either most frequently or most recently. The authors analyzed the obtained results in terms of the three competing models: the storage bin model, according to which the recent construct will be more prominent regardless of the delay period; the battery model, which states that "whichever construct has the advantage after a brief delay" (Higgins, Bargh and Lombardi 1985, 64) will preserve that advantage after longer delays as well; and the synapse model, according to which "the recent construct will have the advantage after a brief delay, but the frequent construct will have the advantage after a long delay" (Higgins, Bargh and Lombardi 1985, 64). Their results showed that if the target stimulus appears almost immediately after the final prime, participants tend to perform the categorization task as a function of the most recently primed element. On the other hand, if there is a longer delay between the final prime and the target stimulus, participants' responses are directed by the frequently primed construct (Higgins, Bargh and Lombardi 1985, 66). The results support the synapse model, according to which "after a sufficient delay, the frequent construct will be at a higher level of action potential than the recent construct, given its slower rate of dissipation" (Higgins, Bargh and Lombardi 1985, 66). Finally, the authors concluded that even momentary or accidental contextual parameters can significantly affect participants' decisions in a categorization task (Higgins, Bargh and Lombardi 1985, 68).

McNamara (1994) performed a series of 4 experiments involving a lexical decision task in order to test the effects of priming via associatively related words, unrelated words, neutral primes, and nonwords. The results indicated that semantic priming occurred in all experiments; 
almost identical RTs and accuracy levels were recorded for priming with unrelated words, neutral words, and nonwords. Between-trials priming did not reveal stronger effects in conditions with non-word and neutral priming, compared to the condition that involved priming with unrelated-words (McNamara 1994: 514). In other words, priming with nonwords "did not inhibit responses, relative to unassociated word primes" (McNamara and Diwadkar 1996, 878), which in turn suggests that lexical decision is affected by the association that exists between the prime and target, rather than only by the prime itself.

Furthermore, the results were discussed in relation to spreading activation models, and non-spreading activation models, and they seem to be more consistent with spreading activation models. In short, with spreading activation models, retrieval from memory involves the activation of internal representations which then spread to related concepts, "and residual activation accumulating at concepts facilitates their retrieval" (McNamara 1994, 507). With non-spreading activation models "memory is searched with a cue that contains information about the target item and the context in which it occurs" (McNamara 1994, 507). If items contained in the cue are associated, the familiarity of the cue increases, and vice versa.

\section{PRESENT RESEARCH}

The present research included two experiments: (i) in the first experiment we tested the activation of the semantic frame of JOURNEY in a lexical decision task, while (ii) in the second experiment we tested the activation of the frame of CONFLICT in a categorization task. Both experiments included the initial stage in which participants were primed through lexical materials for one of the two frames, after which they proceeded to the main task which involved a response time (RT) study based on the two afore mentioned tasks, respectively. Both experiments were designed using Open Sesame (Mathôt, Schreij, and Theeuwes 2012).

\subsection{Experiment 1}

The first experiment was designed to test the activation of the semantic frame of JOURNEY through linguistic priming. The initial priming stage was followed by a lexical decision task which utilized an RT procedure. The study involved two experimental groups: (i) a control group which proceeded directly to the lexical decision task, and (ii) an experimental group which was first primed via lexical content, and then proceeded to the main lexical decision task. In a typical lexical decision task, participants are presented with a string of letters and asked to decide as quickly as possible whether the string represents a word or not. Stimuli typically include words and non-sensical combinations of letters non-words. The main research question which the experiment was designed to answer was: Will lexical priming introduced in the experimental group facilitate participants' RTs to target elements from the semantic frame of motion, compared to the control group?

\subsubsection{Norming study}

The initial part of the research included a norming study, in which we first compiled a list of 114 lexical elements (all nouns and verbal nouns) from the category of JOURNEY. Then we presented these target items to participants in a questionnaire where they were asked to rate how well each lexical element represented the category of JOURNEY. The 
ratings were performed on 6-point Likert scales, with the higher rating corresponding to the higher degree of prototypicality. The norming study included 46 third-year students from the English Department, Faculty of Philosophy, University of Niš. There were 37 female and 9 male participants, with the average age of $21.72(\mathrm{SD}=0.81)$. All participants were native speakers of Serbian.

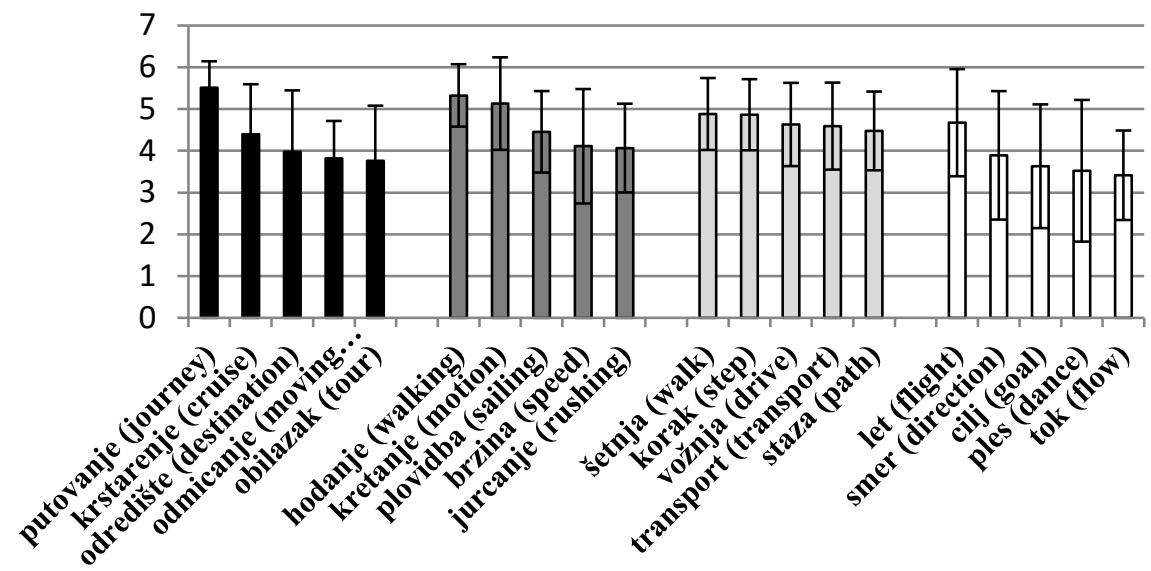

Fig. 1 Target items form the norming study (JOURNEY)

Table 1 Filler items (common categories)

\begin{tabular}{lcc}
\hline Filler & $\begin{array}{c}\text { Syllable } \\
\text { No. }\end{array}$ & Category \\
\hline pas (dog) & 1 & \\
mačka (cat) & 2 & ANIMAL \\
kornjača (turtle) & 3 & \\
alligator (alligator) & 4 & \\
\hline nar (pomegranate) & 1 & \\
limun (lemon) & 2 & FRUIT \\
jabuka (apple) & 3 & \\
pomorandža (orange) & 4 & \\
sport (sport) & 1 & \\
fudbal (football) & 2 & \\
košarka (basketball) & 3 & SPORT \\
vaterpolo (waterloo) & 4 & \\
šal (scarf) & 1 & \\
šešir (hat) & 2 & CLOTHES \\
haljina (dress) & 3 & \\
pantalone (pants) & 4 & \\
stan (apartment) & 1 & \\
kuća (house) & 2 & BUILDING \\
koliba (hut) & 3 & \\
vikendica (cottage) & 4 & \\
\hline
\end{tabular}

For the selection of targets in the main experiment we bore in mind that what readers experience as psychologically real is the number of syllables in a word (Kostić 2010). Accordingly, we selected the five top rated targets containing one, two, three, and four syllables, respectively, which gave a total list of 20 target items (Figure 1). In addition to target items, the main experiment also included 20 filler items selected from 5 common, everyday categories (Table 1), and 28 filler items which included words and non-words. In sum, the main experiment included a total of 68 lexical items which appeared in random order.

\subsubsection{Main experiment}

Forty-seven fourth-year students from the English Department, Faculty of Philosophy, University of Niš, volunteered to take part in the study 
(average age 22.17, $\mathrm{SD}=0.96$ ). Participants (31 female and 16 male) were randomly assigned to one of the two experimental conditions. 24 participants were assigned to the control group and 23 to the experimental group. Participants in the control group proceeded to the lexical decision task in which they were exposed to stimuli (words in Serbian written in small caps, in Latin alphabet) which appeared centered on the screen of a standard PC configuration, with a fixation point between the stimuli in the duration of $450 \mathrm{~ms}$. The order of stimuli was randomized across participants.

\subsubsection{Priming}

The priming procedure was conducted according to the following guidelines: (i) the participants were first asked to read a paragraph in Serbian which described a person on a journey (Figure 2) and (ii) they were asked to identify and write down all lexical items which they believed were connected in any way to the concept of JOURNEY. Each correct lexical item they selected was given a positive score of " +1 ", and each incorrect item was scored as " -1 ". The total priming score was calculated as a sum of scores for each individual item.

Stigao sam u Prag vozom koji je juče ujutru krenuo iz Beograda i pošao da tražim prenoćište. Obišao sam najpre hotele koji su se nalazili oko železničke stanice, čiji su se natpisi mogli videti jedan sa praga drugog i u kojima sam uvek odsedao tokom prethodnih putovanja. Ali sobu nisam dobio, jer, kako su mi objasnili, sve je bilo rezervisano, pa sam morao poći dalje u grad, prema adresama koje su mi redom davali portiri pošto bi me odbili.

Bio je novembar i usled velike hladnoće ježio sam se svaki put kad bih izašao na ulicu da pređem razmak do sledećeg hotela, ali sam sebe prisiljavao da nastavim potragu, znajući da ću u suprotnom noć morati da provedem u čekaonici železničke stanice.

Da ne bih mislio na hladnoću, prisećao sam se putovanja i svih prizora koje sam video kroz prozor voza koji je lagano klizio niz prugu: krivudave seoske putiće, rakrsnice, mostove, a na njima ljude, kamione i automobile, od kojih su neki mileli, a neki jurili, svako svojim poslom. Sve je bilo u konstantom pokretu, kao i ja sada, dok sam tumarao nepoznatim ulicama grada u potrazi za bilo kakvim konačištem.

Fig. 2 Priming material (JOURNEY) ${ }^{2}$

\subsubsection{Between-group comparisons: analysis and results}

The results obtained from the two experimental groups were compared using independent samples t-tests (Table 2). Due to priming which was expected to afford the activation of the semantic frame of JOURNEY, we predicted that the experimental group would show faster RTs to target stimuli compared to the control group which did not receive any priming. Unfortunately, the obtained data did not support our hypothesis.

\footnotetext{
${ }^{2}$ English translation of the priming material is given in Appendix A.
} 
Table 2 Between-group comparisons

\begin{tabular}{|c|c|c|c|c|c|c|}
\hline Target & Exp.group & M & SD & $\mathrm{t}$ & $\mathrm{df}$ & $\mathrm{p}$ \\
\hline \multirow{2}{*}{ Let (flight) } & control & 583.64 & 102.77 & \multirow{2}{*}{0.42} & \multirow{2}{*}{43} & \multirow{2}{*}{.679} \\
\hline & exp. & 571.65 & 90.02 & & & \\
\hline \multirow{2}{*}{ Smer (direction) } & control & 571.64 & 81.57 & \multirow{2}{*}{-0.72} & \multirow{2}{*}{42} & \multirow{2}{*}{.476} \\
\hline & exp. & 595.18 & 129.96 & & & \\
\hline \multirow[b]{2}{*}{ Cilj (goal) } & control & 623.45 & 86.20 & \multirow{2}{*}{0.76} & \multirow[b]{2}{*}{41} & \multirow{2}{*}{.451} \\
\hline & exp. & 602.48 & 94.34 & & & \\
\hline \multirow{2}{*}{ Ples (dance) } & control & 529.42 & 61.88 & \multirow{2}{*}{-1.71} & \multirow{2}{*}{45} & \multirow{2}{*}{.096} \\
\hline & exp. & 574.35 & 110.54 & & & \\
\hline \multirow{2}{*}{ Tok (flow) } & control & 621.91 & 107.45 & \multirow{2}{*}{-1.01} & \multirow{2}{*}{43} & \multirow{2}{*}{.316} \\
\hline & exp. & 654.45 & 107.81 & & & \\
\hline \multirow{2}{*}{ Šetnja (walk) } & control & 578.88 & 87.44 & \multirow{2}{*}{1.45} & \multirow{2}{*}{43} & \multirow{2}{*}{.153} \\
\hline & exp. & 540.62 & 88.67 & & & \\
\hline \multirow{2}{*}{ Korak (step) } & control & 564.66 & 71.36 & 051 & 43 & 615 \\
\hline & exp. & 551.61 & 100.67 & 0.51 & 45 & .015 \\
\hline & control & 528.34 & 78.44 & 201 & & 056 \\
\hline voznja (arive) & exp. & 629.40 & 212.16 & -2.01 & 41 & $.0 \$ 0$ \\
\hline Transnort (transnort) & control & 599.81 & 83.10 & $=038$ & 41 & 706 \\
\hline Iranspont (transport) & exp. & 610.90 & 107.37 & -0.50 & 41 & .100 \\
\hline & control & 559.73 & 69.38 & & & \\
\hline staza $(p a t h)$ & exp. & 606.47 & 132.08 & -1.49 & 42 & .144 \\
\hline Hodanie (walking) & control & 602.59 & 71.30 & 036 & 42 & 721 \\
\hline Hodanje (waiking) & exp. & 613.77 & 126.98 & -0.50 & 42 & .121 \\
\hline Kretanie (motion) & control & 582.91 & 92.72 & 056 & 42 & 578 \\
\hline nretanje (molion) & exp. & 567.23 & 92.68 & & & \\
\hline Plovidhe (sailing) & control & 739.39 & 214.50 & 242 & $A \cap$ & ר? \\
\hline Fiovidod (sailing) & exp. & 618.52 & 97.43 & 2.42 & 40 & $.0 \angle 2$ \\
\hline Brzina (sneed) & control & 557.81 & 102.88 & -045 & 42 & 655 \\
\hline Brzina (speea) & exp. & 571.40 & 97.41 & -0.45 & 42 & .05 \\
\hline Iurcanie (rushing) & control & 702.54 & 172.22 & 030 & 40 & 760 \\
\hline Jurcanje (rusning) & exp. & 685.65 & 198.22 & 0.50 & 40 & .109 \\
\hline Putovanie (iournoy) & control & 572.04 & 83.01 & -02 & 40 & 982 \\
\hline Putovanje (journey) & exp. & 572.65 & 85.42 & -.02 & 40 & .982 \\
\hline Krstarenie (sruise) & control & 625.78 & 84.92 & 08 & 43 & 336 \\
\hline Krstarenje (cruise) & exp. & 665.77 & 172.92 & -0.98 & 43 & .350 \\
\hline Odredište (destination) & control & 593.86 & 113.61 & -112 & 44 & 267 \\
\hline Uarearste (aestinaion) & exp. & 636.91 & 144.48 & -1.12 & 44 & .201 \\
\hline & control & 688.21 & 142.27 & 2,65 & & \\
\hline Udmicanje (moving away) & exp. & 587.78 & 92.17 & 2.05 & 40 & .012 \\
\hline Obilazak (tour) & control & 609.86 & 90.96 & 000 & & \\
\hline Oonazak (tour) & exp. & 607.31 & 96.56 & 0.09 & 42 & .929 \\
\hline
\end{tabular}

We subtracted the obtained mean RTs for targets recorded in the experimental group from those recorded in the control group. Positive values in Figure 2 show slower RTs in the control group, while negative values show slower RTs in the experimental group the experimental group recorded faster RTs to targets only in 8 cases, of which only two results 
were significant (plovidba $a^{3}$ and odmicanje ( $^{4}$. On the other hand, the control group showed faster RTs in all of the remaining cases, where only vožnja ${ }^{5}$ reached marginal significance.

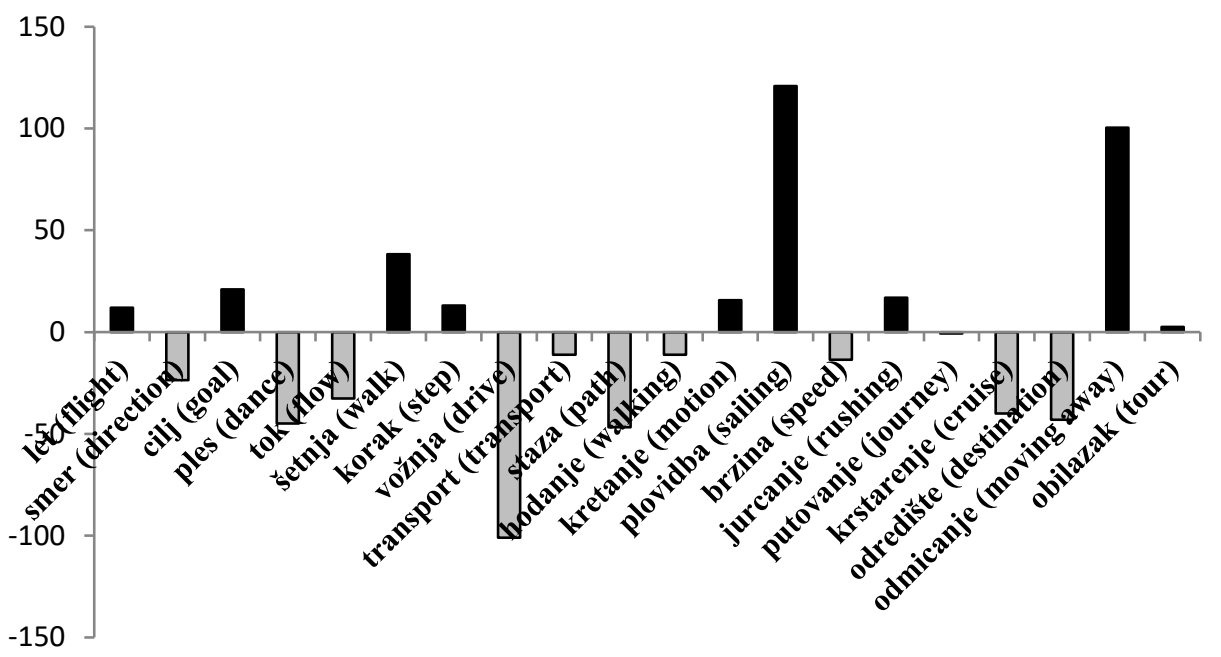

Fig. 2 [RT $\left.\mathrm{R}_{\text {control group }}-\mathrm{RT}_{\text {experimental group }}\right]$

Based on the obtained mean values for targets in the two experimental groups we also calculated the overall mean tendencies in each of the groups and ran repeated measures ANOVA. The result did not reach significance, and there was a negligible difference of $1.38 \mathrm{~ms}$ in favor of the control group $(\mathrm{F}(1,19)=0.15$, Wilks's Lambda $=.999, \mathrm{p}=.903$, multivariate partial eta squared=.001, $\mathrm{M}_{\mathrm{exp}}=603.21 \mathrm{~ms}, \mathrm{SD}_{\mathrm{exp}}=38.07 \mathrm{~ms}, \mathrm{M}_{\text {control }}=601.83 \mathrm{~ms}$, $\mathrm{SD}_{\text {control }}=54.70 \mathrm{~ms}$ ). Also, there were no significant differences in priming scores between the two experimental groups $\left(\mathrm{M}_{\exp }=10.39, \mathrm{SD}_{\mathrm{exp}}=2.59, \mathrm{M}_{\text {contr. }}=10.42, \mathrm{SD}_{\text {contr. }}=2.69\right.$, $\mathrm{t}=0.033, \mathrm{df}=45, \mathrm{p}=.974)$.

\subsubsection{Discussion}

The obtained results suggest that lexical priming in the experimental group did not afford faster RTs to target stimuli compared to the control group. We offer two possible explanations for such findings.

Firstly, the highly entrenched nature of the JOURNEY frame which permeates everyday reality might override the semantic priming. Namely, bearing in mind that everyday interaction is unimaginable without at least some resort to motion, either literal or metaphorical, one possible explanation for the obtained results is that priming simply did not work. In other words, reading semantic content with lexical items describing motion, and subsequent identification of specific lexical items related to motion may not be enough to provide sufficient bias in the experimental group, which would license faster RTs in the lexical decision task, compared to the control group, which did not undergo such a procedure. Secondly, the lexical decision task

\footnotetext{
3 sailing

${ }^{4}$ moving away

${ }^{5}$ drive
} 
may not be the best choice to test the activation of semantic frames. To be precise, the task itself may be too simple, thereby moving the focus from the primed semantic content onto an easier cognitive task. By reducing the cognitive load, the lexical decision task may, in fact, override the priming procedure.

Owing to the fact that the first experiment did not yield expected results, we designed a second experiment which involved new priming material related to the frame of CONFLICT, and a new main task which involved categorization of target items.

\subsection{Experiment 2}

The second experiment was designed to test the activation of the semantic frame of CONFLICT through semantic priming. The procedure was identical to the one used in the first experiment. The main research question which the second experiment was designed to answer was: Will lexical priming introduced in the experimental group facilitate participants' RTs to target elements from the CONFLICT frame, compared to the control group?

\subsubsection{Norming study}

In the initial stage, a norming study was performed in order to facilitate the selection of target stimuli. The norming study included thirty-six third-year students from the English Department, Faculty of Philosophy, University of Niš. There were 30 female and 6 male participants with the average age of 21.53 ( $\mathrm{SD}=0.65)$. As in the first experiment above, we compiled a list of 109 nouns and verbal nouns related to the category of CONFLICT rated on 6-point Likert scales, with higher values corresponding to higher levels of prototipicality. The norming study yielded a list of 20 target items (Figure 3). The list of filler items was identical to those used in the first experiment.

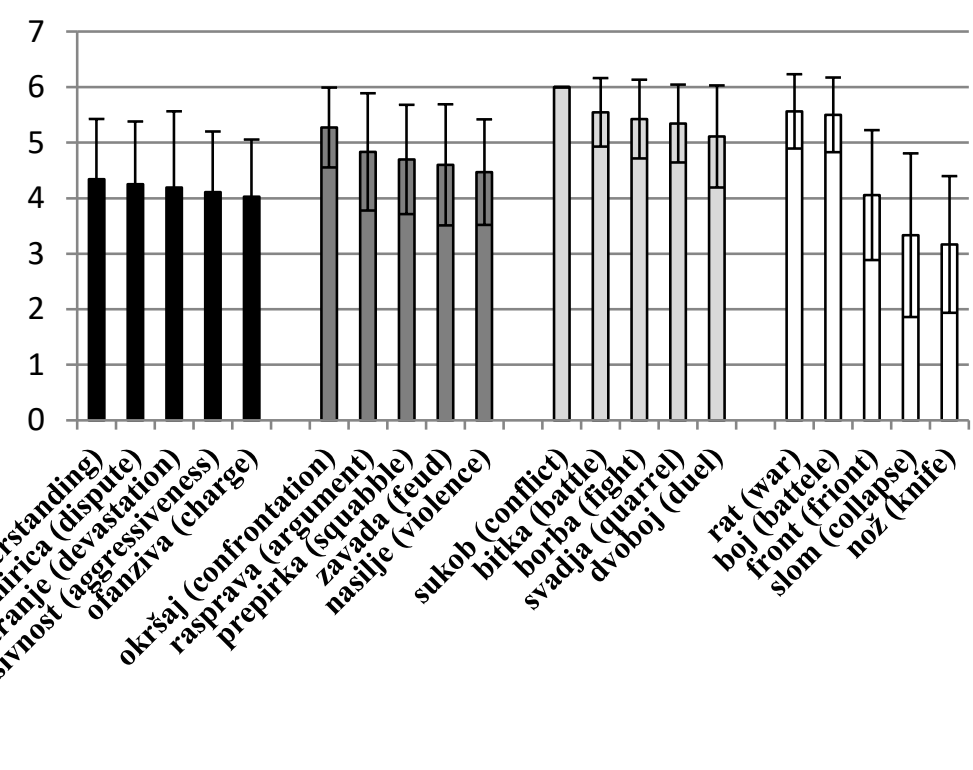

Fig. 3 Target items form the norming study (CONFLICT) 


\subsubsection{Main experiment}

Sixty-eight second-year students from the English Department, Faculty of Philosophy, University of Niš volunteered to take part in the study. There were 50 female and 18 male participants, with the average age of $20.76(\mathrm{SD}=0.72)$. Participants were randomly assigned to one of the two experimental groups, with 35 participants in the experimental, and 33 in the control group.

The second experiment followed the same procedure used in the first experiment. The control group proceeded directly to the categorization task in which the participants were instructed to decide as quickly as possible whether the lexical element on the screen was a good representative of the category of CONFLICT or not. The experimental group was first primed for the semantic frame of CONFLICT (Figure 4), and then proceeded to the main categorization task. Stimuli (words in Serbian written in small caps, in Latin alphabet) were presented centered on the screen of a standard PC configuration, with a fixation point between the stimuli in the duration of $450 \mathrm{~ms}$. The order of stimuli was randomized across participants. The relevant variable recorded in Open Sesame was participants' response time measured in milliseconds [ms].

\subsubsection{Priming}

The priming procedure was also conducted similarly to the first experiment: (i) the participants were first asked to read a paragraph in Serbian which contained a description of military organization (Figure 4), after which (ii) they were asked to identify and write down all lexical items which they believed were connected in any way to the concept of CONFLICT. The total priming score was calculated like in the first experiment.

Filip II, otac Aleksandra Velikog, posedovao je veliki dar za vojne poslove i za upravljanje države, pa mu nije bilo teško da reformiše politički i vojni sistem svoje zemlje. Od feudalne države sa rodovskim uređenjem stvorio je moćnu silu kojom je upravljao jedan čovek i koja je imala dobro uvežbanu i dobro snabdevenu vojsku. I zaista, najveću pažnju Filip je posvetio organizaciji i taktičkoj obuci makedonske armije. Svoju nadmoć je potom iskoristio za ujedinjenje polisa pod svojom upravom kako bi stvorio dovoljnu veliku vojsku za koju se nadao da će mu omogućiti da savlada svog velikog neprijatelja-Persiju.

Filip je stvorio falangu, odred pešaka naoružanih kopljima dugim oko pet metara, i čija udarna snaga nije imala sebi ravnog $\mathrm{u}$ tadašnjem svetu. Posebni deo pešadije činili su štitonoše, lakše naoružani od falangita pa su zato imali drugačiju ulogu u borbi. Osim njih, neizostavni deo vojske bila je i makedonska konjica, koja je bila veoma snažna i nju su činili plemići naoružani kopljima i mačevima, a postojao je i drugi rod konjice - kopljanici. U svom sastavu Filipova armija je takođe imala i strelce, lako naoružanu pešadiju i veliki broj grčkih najamnika.

Fig. 4 Priming material (CONFLICT) ${ }^{6}$

\footnotetext{
${ }^{6}$ English translation of the priming material is given in Appendix B.
} 
4.2.4. Between-group comparisons: analysis and results

Independent samples t-tests were used to compare mean RTs for targets recorded in the two experimental groups (Table 3). Although there was only one case which yielded significance $\left(\right.$ nasilje $\left.^{7}\right)$, and one marginal significance $\left(\right.$ agresivnost $\left.^{8}\right)$, both showing significantly faster RTs

Table 3 Between-group comparisons

\begin{tabular}{|c|c|c|c|c|c|c|}
\hline Target & Exp. group & $\mathrm{M}$ & $\mathrm{SD}$ & $\mathrm{t}$ & $\mathrm{df}$ & $\mathrm{p}$ \\
\hline Rat (war) & $\begin{array}{l}\text { experimental } \\
\text { control }\end{array}$ & $\begin{array}{l}630.15 \\
675.25\end{array}$ & $\begin{array}{l}106.73 \\
162.29\end{array}$ & -1.31 & 62 & .194 \\
\hline Boj (battle) & $\begin{array}{l}\text { experimental } \\
\text { control }\end{array}$ & $\begin{array}{l}641.19 \\
641.06\end{array}$ & $\begin{array}{r}94.53 \\
103.96\end{array}$ & 0.01 & 60 & .996 \\
\hline Front (front) & $\begin{array}{l}\text { experimental } \\
\text { control }\end{array}$ & $\begin{array}{l}773.12 \\
854.12\end{array}$ & $\begin{array}{l}277.52 \\
303.57\end{array}$ & -1.12 & 63 & .266 \\
\hline Slom (collapse) & $\begin{array}{l}\text { experimental } \\
\text { control }\end{array}$ & $\begin{array}{l}861.20 \\
775.83\end{array}$ & $\begin{array}{l}242.25 \\
257.92\end{array}$ & 1.38 & 63 & .174 \\
\hline Nož (knife) & $\begin{array}{l}\text { experimental } \\
\text { control }\end{array}$ & $\begin{array}{l}659.93 \\
738.80\end{array}$ & $\begin{array}{l}155.12 \\
249.03\end{array}$ & -1.51 & 62 & .131 \\
\hline Sukob (conflict) & $\begin{array}{l}\text { experimental } \\
\text { control }\end{array}$ & $\begin{array}{l}632.18 \\
661.78\end{array}$ & $\begin{array}{l}129.22 \\
115.38\end{array}$ & -0.97 & 63 & .334 \\
\hline Bitka (combat) & $\begin{array}{l}\text { experimental } \\
\text { control }\end{array}$ & $\begin{array}{l}598.30 \\
642.34\end{array}$ & $\begin{array}{r}94.71 \\
102.09\end{array}$ & -1.76 & 60 & .084 \\
\hline Borba (fight) & $\begin{array}{l}\text { experimental } \\
\text { control }\end{array}$ & $\begin{array}{l}639.48 \\
663.38\end{array}$ & $\begin{array}{l}121.05 \\
133.45\end{array}$ & -0.75 & 62 & .455 \\
\hline Svađa (quarrel) & $\begin{array}{l}\text { experimental } \\
\text { control }\end{array}$ & $\begin{array}{l}611.93 \\
626.16\end{array}$ & $\begin{array}{l}100.45 \\
125.03\end{array}$ & -0.49 & 59 & .627 \\
\hline Dvoboj (duel) & $\begin{array}{l}\text { experimental } \\
\text { control }\end{array}$ & $\begin{array}{l}674.71 \\
691.93\end{array}$ & $\begin{array}{r}124.32 \\
95.54\end{array}$ & -0.62 & 62 & .537 \\
\hline Okršaj (confrontation) & $\begin{array}{l}\text { experimental } \\
\text { control }\end{array}$ & $\begin{array}{l}667.90 \\
697.03\end{array}$ & $\begin{array}{r}84.16 \\
124.29\end{array}$ & -1.07 & 59 & .290 \\
\hline Rasprava (argument) & $\begin{array}{l}\text { experimental } \\
\text { control }\end{array}$ & $\begin{array}{l}663.32 \\
681.03\end{array}$ & $\begin{array}{l}127.27 \\
121.08\end{array}$ & -0.58 & 64 & .565 \\
\hline Prepirka (squabble) & $\begin{array}{l}\text { experimental } \\
\text { control }\end{array}$ & $\begin{array}{l}854.52 \\
792.00\end{array}$ & $\begin{array}{l}253.48 \\
315.61\end{array}$ & 0.89 & 64 & .377 \\
\hline Zavada (feud) & $\begin{array}{l}\text { experimental } \\
\text { control }\end{array}$ & $\begin{array}{l}806.85 \\
779.21\end{array}$ & $\begin{array}{l}232.83 \\
262.47\end{array}$ & 0.46 & 66 & .647 \\
\hline Nasilje (violence) & $\begin{array}{l}\text { experimental } \\
\text { control }\end{array}$ & $\begin{array}{l}621.84 \\
721.62\end{array}$ & $\begin{array}{l}108.58 \\
157.07\end{array}$ & -2.96 & 62 & .004 \\
\hline $\begin{array}{l}\text { Nesporazum } \\
\text { (misunderstanding) }\end{array}$ & $\begin{array}{l}\text { experimental } \\
\text { control }\end{array}$ & $\begin{array}{l}695.30 \\
742.90\end{array}$ & $\begin{array}{l}132.02 \\
166.50\end{array}$ & -1.27 & 62 & .208 \\
\hline Razmirica (dispute) & $\begin{array}{l}\text { experimental } \\
\text { control }\end{array}$ & $\begin{array}{r}967.38 \\
1120.33\end{array}$ & $\begin{array}{l}306.88 \\
487.97\end{array}$ & -1.51 & 62 & .137 \\
\hline $\begin{array}{l}\text { Razaranje } \\
\text { (devastation) }\end{array}$ & $\begin{array}{l}\text { experimental } \\
\text { control }\end{array}$ & $\begin{array}{l}837.69 \\
850.09\end{array}$ & $\begin{array}{l}247.87 \\
215.48\end{array}$ & -0.21 & 62 & .832 \\
\hline $\begin{array}{l}\text { Agresivnost } \\
\text { (aggressiveness) }\end{array}$ & $\begin{array}{l}\text { experimental } \\
\text { control }\end{array}$ & $\begin{array}{l}707.66 \\
920.69\end{array}$ & $\begin{array}{l}144.28 \\
598.75\end{array}$ & -1.99 & 64 & .045 \\
\hline Ofanziva (charge) & $\begin{array}{l}\text { experimental } \\
\text { control }\end{array}$ & $\begin{array}{l}763.21 \\
874.33\end{array}$ & $\begin{array}{l}215.86 \\
324.34\end{array}$ & -1.64 & 64 & .106 \\
\hline
\end{tabular}

${ }^{7}$ violence

${ }^{8}$ aggressiveness 
in the experimental group, an overview of mean values shows clear advantage in favor of the experimental group which showed consistently faster RTs to the majority of target stimuli. There were no differences in priming scores between the two experimental groups $\left(\mathrm{M}_{\mathrm{exp}}=19.23\right.$, $\left.\mathrm{SD}_{\text {exp }}=3.50, \mathrm{M}_{\text {contr }}=19.55, \mathrm{SD}_{\text {contr }}=3.88, \mathrm{t}=-0.355, \mathrm{df}=66, \mathrm{p}=.724\right)$.

We again subtracted the mean RTs for targets recorded in the experimental group from those recorded in the control group. The results are presented in Figure 5. Positive values suggest faster reaction times in the experimental group, while negative values signal faster response times in the control group. It is obvious that in the case of a categorization task used in the second experiment the majority of target items showed the expected tendency. The experimental group showed faster reaction times for the majority of targets, compared to the control group. This suggests that the activation of the semantic frame of CONFLICT introduced through the semantic priming procedure licensed faster decision making in the categorization task.

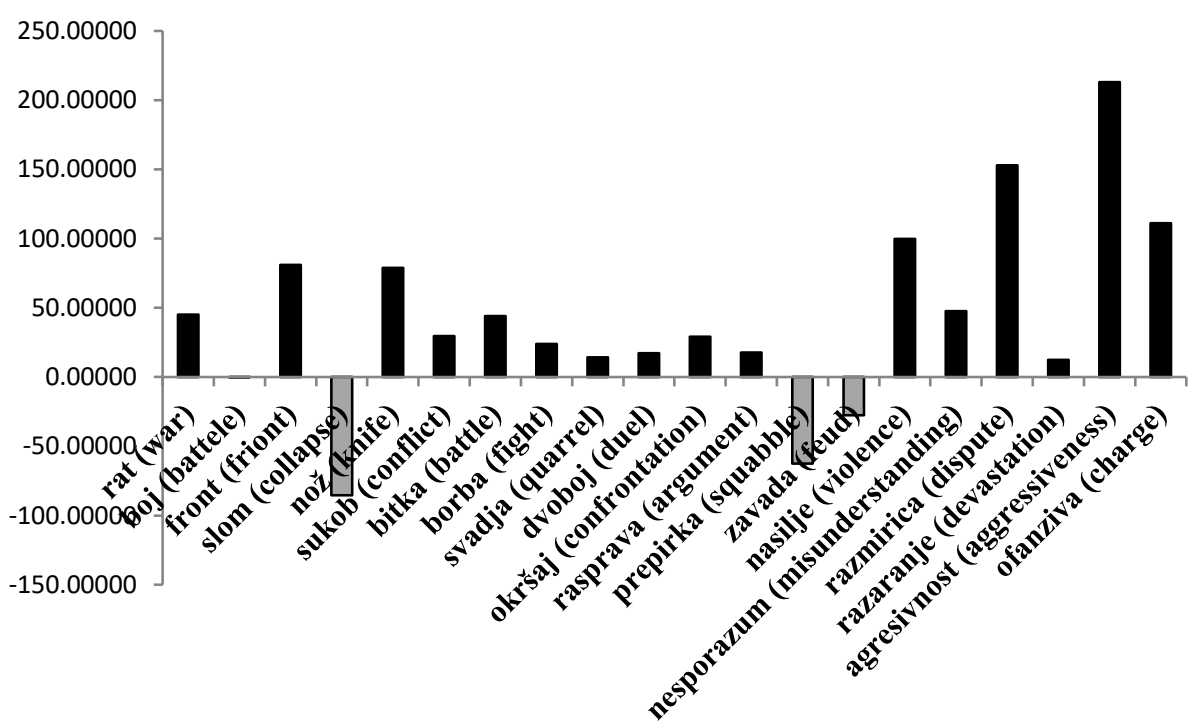

Fig. 5 [RT $\left.\mathrm{R}_{\text {control group }}-\mathrm{RT}_{\text {experimental group }}\right]$

Based on the mean values obtained for targets in the two experimental groups, the overall mean tendencies in each of the groups for the selected targets were compared using repeated measures ANOVA. The analysis revealed significantly faster RTs to target stimuli in the experimental group compared to the control group $(\mathrm{F}(1,19)=7.49$, Wilks's Lambda $=.72, \mathrm{p}=.013$, multivariate partial eta squared $=.28, \mathrm{M}_{\mathrm{exp}}=715.40 \mathrm{~ms}, \mathrm{SD}_{\exp }=103.07 \mathrm{~ms}$, $\mathrm{M}_{\text {control }}=757.50 \mathrm{~ms}, \mathrm{SD}_{\text {control }}=120.60 \mathrm{~ms}$ ).

The comparison of overall mean tendencies for filler items between the two groups did not yield significance $(\mathrm{F}(1,19)=0.002, \mathrm{p}=.961)$, which suggests that the priming condition successfully biased participants' RTs only for target items from the semantic frame of CONFLICT. 


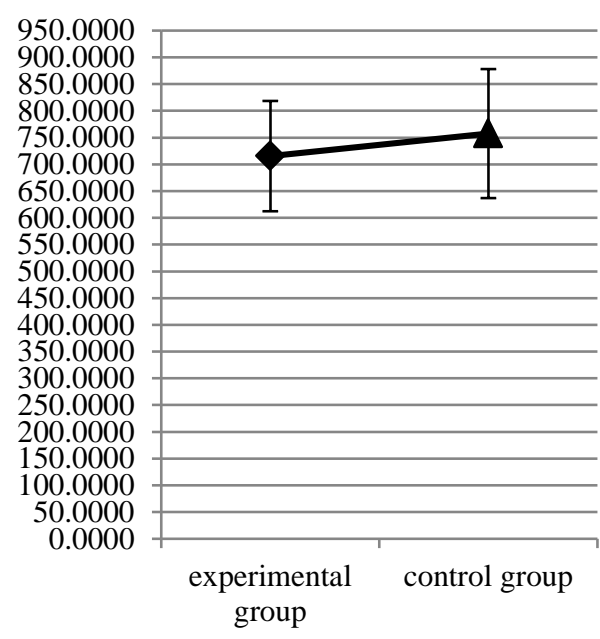

Fig. 6 Overall mean RTs

\subsubsection{Discussion}

The obtained results support the idea that semantic priming can afford the activation of a semantic frame, which was reflected in faster RTs to target stimuli recorded in the experimental group. In that sense, the categorization task seems to be a more suitable solution for testing semantic frame activation in an RT paradigm, compared to the lexical decision task used in the first experiment. However, despite the positive results recorded in the second experiment, some questions still remain unanswered. These will be addressed in the following sections.

\section{COMPARISON OF EXPERIMENTAL AND CONTROL GROUPS BETWEEN EXPERIMENTS 1 AND 2: FILLER ITEMS}

Bearing in mind that the obtained results raise the question of suitability of the lexical decision task for testing the activation of a semantic frame via semantic priming in a subsequent RT paradigm, we decided to compare mean RTs recorded for filler items which occurred in both experiments, between the two experimental groups and between the two control groups from experiments 1 and 2. This was done in order to test the hypothesis that the lexical decision task was too simple and that it served as an override to the initial priming task. If this hypothesis is true, we expect that RTs recorded for filler items in the experimental group from Experiment 2 will be consistently longer compared to those recorded in the experimental group from Experiment 1. Also, we expect a similar result for the comparison of control groups from the two experiments. If lexical decision is indeed a simpler task with a reduced cognitive load compared to the categorization task, its effect should be evident for all items used in the experiment, not only for the main targets. If, on the other hand, our hypothesis is false, and there are no differences in difficulty between the lexical decision and categorization task, then there should not be any significant differences in RTs for filler items between the two experiments.

\subsection{Comparison of experimental groups}

Independent samples t-tests were used to compare mean RTs for filler items between experimental groups from the two experiments. The obtained results support our hypothesis, as the recorded means in the experimental group from Experiment 2 were consistently slower compared to the corresponding means recorded in the experimental group in Experiment 1. Moreover, apart from two items $\left(n a r^{9}\right.$ and $\left.\operatorname{limun}^{10}\right)$, all of the remaining differences reached significance (Table 4).

\footnotetext{
${ }^{9}$ pomegranate

${ }^{10}$ lemon
} 
Table 4 Filler items in experimental groups

\begin{tabular}{|c|c|c|c|c|c|c|}
\hline Filler & Experimental group & M & SD & $\mathrm{t}$ & $\mathrm{df}$ & $\mathrm{p}$ \\
\hline \multirow{2}{*}{ Pas $(d o g)$} & Exp. 2 exp. gr. & 639.94 & 174.11 & \multirow{2}{*}{2.41} & \multirow{2}{*}{56} & \multirow{2}{*}{.019} \\
\hline & Exp. 1 exp. gr. & 544.56 & 92.93 & & & \\
\hline \multirow{2}{*}{ Mačka (cat) } & Exp. 2 exp. gr. & 647.97 & 164.64 & \multirow{2}{*}{6.36} & \multirow{2}{*}{55} & \multirow{2}{*}{.001} \\
\hline & Exp. 1 exp. gr. & 510.31 & 79.90 & & & \\
\hline \multirow{2}{*}{ Kornjača (turtle) } & Exp. 2 exp. gr. & 794.57 & 257.73 & \multirow{2}{*}{4.67} & \multirow{2}{*}{57} & \multirow{2}{*}{$<.001$} \\
\hline & Exp. 1 exp. gr. & 576.58 & 81.70 & & & \\
\hline \multirow{2}{*}{ Alligator (alligator) } & Exp. 2 exp. gr. & 844.65 & 364.96 & \multirow{2}{*}{3.62} & \multirow{2}{*}{55} & \multirow{2}{*}{.001} \\
\hline & Exp. 1 exp. gr. & 617.13 & 56.28 & & & \\
\hline \multirow{2}{*}{ Nar (pomegranate) } & Exp. 2 exp. gr. & 777.00 & 434.06 & \multirow{2}{*}{1.16} & \multirow{2}{*}{55} & \multirow{2}{*}{.251} \\
\hline & Exp. 1 exp. gr. & 665.09 & 155.00 & & & \\
\hline \multirow{2}{*}{ Limun (lemon) } & Exp. 2 exp. gr. & 657.88 & 144.22 & \multirow{2}{*}{1.61} & \multirow{2}{*}{57} & \multirow{2}{*}{.113} \\
\hline & Exp. 1 exp. gr. & 604.45 & 90.59 & & & \\
\hline \multirow{2}{*}{ Jabuka (apple) } & Exp. 2 exp. gr. & 628.00 & 111.20 & & & \\
\hline & Exp. 1 exp. gr. & 525.59 & 41.32 & 4.93 & 35 &. .001 \\
\hline Pomorandža (aranos) & Exp. 2 exp. gr. & 715.97 & 199.89 & 306 & 56 & 003 \\
\hline 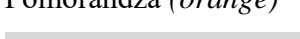 & Exp. 1 exp. gr. & 592.17 & 106.74 & 5.00 & 30 & .000 \\
\hline Sport (sport) & Exp. 2 exp. gr. & 756.65 & 286.41 & 425 & 57 & $<001$ \\
\hline spoti (sport) & Exp. 1 exp. gr. & 540.41 & 75.95 & 4.25 & 21 & \\
\hline Fudhal (forthall) & Exp. 2 exp. gr. & 807.37 & 362.59 & $354+25>030$ & 57 & 001 \\
\hline 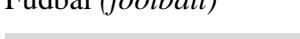 & Exp. 1 exp. gr. & 579.04 & 98.14 & 5.34 & 31 & .001 \\
\hline Košarka (basketball) & Exp. 2 exp. gr. & 712.85 & 245.30 & 3.02 & 55 & 004 \\
\hline 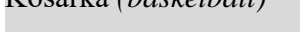 & Exp. 1 exp. gr. & 565.95 & 119.32 & 5.02 & J2 & .004 \\
\hline Vaternolo (water nolo) & Exp. 2 exp. gr. & 794.02 & 256.98 & 342 & 55 & 001 \\
\hline vaterpoio (waler poio) & Exp. 1 exp. gr. & 627.77 & 101.72 & 5.42 & SJ & .001 \\
\hline Šal (scarf) & Exp. 2 exp. gr. & 774.02 & 386.25 & 265 & 55 & 012 \\
\hline Sal (scarg) & Exp. 1 exp. gr. & 595.54 & 80.06 & $2.0 \mathrm{~J}$ & J2 & .012 \\
\hline Šešir (hat) & Exp. 2 exp. gr. & 668.11 & 167.88 & 293 & & 005 \\
\hline Sesir (nat) & Exp. 1 exp. gr. & 567.40 & 91.32 & 2.95 & 55 & .000 \\
\hline Haliina (dress) & Exp. 2 exp. gr. & 797.05 & 375.57 & 3.41 & 56 & 002 \\
\hline maijuma (aress) & Exp. 1 exp. gr. & 571.73 & 87.37 & 3.41 & 30 & .002 \\
\hline Pantalone (pants) & Exp. 2 exp. gr. & 776.80 & 342.60 & 320 & 57 & 002 \\
\hline Pantalone (pants) & Exp. 1 exp. gr. & 578.87 & 80.90 & 5.29 & 31 & .002 \\
\hline Stan (anartment) & Exp. 2 exp. gr. & 725.08 & 173.78 & 363 & 57 & 001 \\
\hline scan (арагінет) & Exp. 1 exp. gr. & 580.12 & 107.37 & 5.03 & $\pi$ & .001 \\
\hline Kuća (house) & Exp. 2 exp. gr. & 749.17 & 312.18 & 3.65 & 56 & .0015 \\
\hline Nuca (nouse) & Exp. 1 exp. gr. & 544.91 & 90.28 & 5.05 & 30 & .0015 \\
\hline Koliba (hut) & Exp. 2 exp. gr. & 884.60 & 300.21 & 5.48 & 57 & \\
\hline nomod (nul) & Exp. 1 exp. gr. & 588.79 & 90.09 & 5.40 & 31 &. .001 \\
\hline Vikendica (cottage) & Exp. 2 exp. gr. & 799.00 & 294.59 & 3.71 & 56 & 001 \\
\hline enume (collage) & Exp. 1 exp. gr. & 604.30 & 80.05 & 5.11 & 50 & .001 \\
\hline
\end{tabular}

We also calculated the overall mean tendencies for the first group of filler items in the two respective experimental groups. Repeated measures ANOVA also revealed significantly longer overall mean RTs in the experimental group from Experiment 2 $(\mathrm{F}(1,19)=156.61$, Wilks's Lambda $=.11, \mathrm{p}<.001$, multivariate partial eta squared $=.89$, Mexp_1 $=579.04 \mathrm{~ms}$, SDexp $\_1=36.16 \mathrm{~ms}, \operatorname{Mexp} \_2=747.54 \mathrm{~ms}$, SDexp $\_2=71.31 \mathrm{~ms}$ ). 


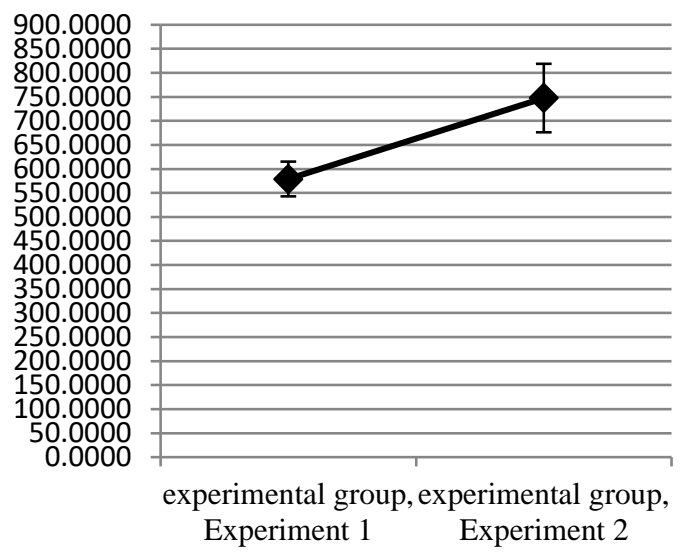

Fig. 7 Repeated measures ANOVA

\subsection{Comparison of control groups}

Independent samples t-tests were also used to compare mean RTs for filler items between control groups from the two experiments. The results supported our hypothesis since, apart from two items (alligator ${ }^{l 1}$ and $n a r^{l 2}$ ), all of the remaining differences reached significance, with slower RTs recorded in the control group from the second experiment (Table 5).

The comparison of overall mean tendencies for filler items in the two control groups also showed significantly slower RTs recorded in the second experiment $(\mathrm{F}(1,19)=156.50$, Wilks's Lambda $=.11, \mathrm{p}<.001$, multivariate partial eta squared $=.89, \mathrm{M}_{\exp 1}=590.12 \mathrm{~ms}$, $\mathrm{SD}_{\exp 1}=53.89 \mathrm{~ms}, \mathrm{M}_{\exp 2}=748.21 \mathrm{~ms}, \mathrm{SD}_{\exp 2}=49.46 \mathrm{~ms}$ ).

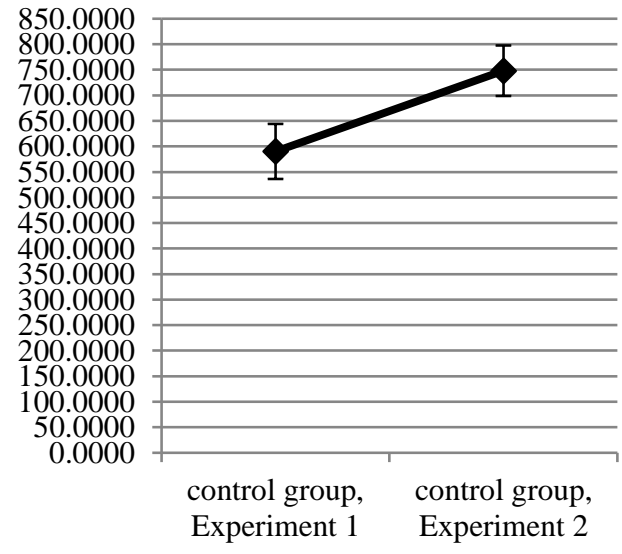

Fig. 8 Repeated measures ANOVA

\footnotetext{
11 alligator

${ }^{12}$ pomegranate
} 
Table 5 Filler items in control groups

\begin{tabular}{|c|c|c|c|c|c|c|}
\hline Filler & Experimental group & M & SD & $\mathrm{t}$ & $\mathrm{df}$ & $\mathrm{p}$ \\
\hline $\operatorname{Pas}(d o g)$ & $\begin{array}{l}\text { Exp. } 2 \text { contr. gr. } \\
\text { Exp. } 1 \text { contr. gr. }\end{array}$ & $\begin{array}{l}769.87 \\
561.31\end{array}$ & $\begin{array}{l}387.04 \\
104.07\end{array}$ & 2.94 & 53 & .006 \\
\hline Mačka (cat) & $\begin{array}{l}\text { Exp. } 2 \text { contr. gr. } \\
\text { Exp. } 1 \text { contr. gr. }\end{array}$ & $\begin{array}{l}727.57 \\
511.00\end{array}$ & $\begin{array}{r}261.31 \\
63.44\end{array}$ & 4.54 & 50 & $<.001$ \\
\hline Kornjača (turtle) & $\begin{array}{l}\text { Exp. } 2 \text { contr. gr. } \\
\text { Exp. } 1 \text { contr. gr. }\end{array}$ & $\begin{array}{l}849.63 \\
570.00\end{array}$ & $\begin{array}{l}451.20 \\
113.39\end{array}$ & 3.39 & 51 & .002 \\
\hline Alligator (alligator) & $\begin{array}{l}\text { Exp. } 2 \text { contr. gr. } \\
\text { Exp. } 1 \text { contr. gr. }\end{array}$ & $\begin{array}{l}768.66 \\
730.39\end{array}$ & $\begin{array}{l}283.14 \\
224.78\end{array}$ & 0.54 & 54 & .591 \\
\hline Nar (pomegranate) & $\begin{array}{l}\text { Exp. } 2 \text { contr. gr. } \\
\text { Exp. } 1 \text { contr. gr. }\end{array}$ & $\begin{array}{l}821.39 \\
674.31\end{array}$ & $\begin{array}{l}833.22 \\
126.05\end{array}$ & 0.82 & 53 & .416 \\
\hline Limun (lemon) & $\begin{array}{l}\text { Exp. } 2 \text { contr. gr. } \\
\text { Exp. } 1 \text { contr. gr. }\end{array}$ & $\begin{array}{l}707.48 \\
575.38\end{array}$ & $\begin{array}{l}250.51 \\
114.47\end{array}$ & 2.27 & 52 & .028 \\
\hline Jabuka (apple) & $\begin{array}{l}\text { Exp. } 2 \text { contr. gr. } \\
\text { Exp. } 1 \text { contr. gr. }\end{array}$ & $\begin{array}{l}646.48 \\
559.78\end{array}$ & $\begin{array}{l}148.35 \\
104.14\end{array}$ & 2.42 & 54 & .019 \\
\hline Pomorandža (orange) & $\begin{array}{l}\text { Exp. } 2 \text { contr. gr. } \\
\text { Exp. } 1 \text { contr. gr. }\end{array}$ & $\begin{array}{l}738.54 \\
616.42\end{array}$ & $\begin{array}{l}246.54 \\
131.27\end{array}$ & 2.37 & 52 & .022 \\
\hline Sport (sport) & $\begin{array}{l}\text { Exp. } 2 \text { contr. gr. } \\
\text { Exp. } 1 \text { contr. gr. }\end{array}$ & $\begin{array}{l}796.57 \\
540.00\end{array}$ & $\begin{array}{r}334.62 \\
76.34\end{array}$ & 4.23 & 51 & $<.001$ \\
\hline Fudbal (football) & $\begin{array}{l}\text { Exp. } 2 \text { contr. gr. } \\
\text { Exp. } 1 \text { contr. gr. }\end{array}$ & $\begin{array}{l}736.18 \\
564.09\end{array}$ & $\begin{array}{l}251.17 \\
119.75\end{array}$ & 2.99 & 53 & .004 \\
\hline Košarka (basketball) & $\begin{array}{l}\text { Exp. } 2 \text { contr. gr. } \\
\text { Exp. } 1 \text { contr. gr. }\end{array}$ & $\begin{array}{l}706.78 \\
534.09\end{array}$ & $\begin{array}{r}210.07 \\
91.58\end{array}$ & 4.14 & 52 & $<.001$ \\
\hline Vaterpolo (water polo) & $\begin{array}{l}\text { Exp. } 2 \text { contr. gr. } \\
\text { Exp. } 1 \text { contr. gr. }\end{array}$ & $\begin{array}{l}794.09 \\
675.09\end{array}$ & $\begin{array}{l}252.80 \\
142.12\end{array}$ & 2.21 & 52 & .032 \\
\hline Šal (scarf) & $\begin{array}{l}\text { Exp. } 2 \text { contr. gr. } \\
\text { Exp. } 1 \text { contr. gr. }\end{array}$ & $\begin{array}{l}761.12 \\
586.19\end{array}$ & $\begin{array}{l}199.81 \\
121.90\end{array}$ & 4.00 & 52 & $<.001$ \\
\hline Šešir (hat) & $\begin{array}{l}\text { Exp. } 2 \text { contr. gr. } \\
\text { Exp. } 1 \text { contr. gr. }\end{array}$ & $\begin{array}{l}690.87 \\
570.86\end{array}$ & $\begin{array}{l}214.20 \\
110.66\end{array}$ & 2.42 & 53 & .019 \\
\hline Haljina (dress) & $\begin{array}{l}\text { Exp. } 2 \text { contr. gr. } \\
\text { Exp. } 1 \text { contr. gr. }\end{array}$ & $\begin{array}{l}710.54 \\
602.31\end{array}$ & $\begin{array}{l}207.02 \\
120.47\end{array}$ & 2.21 & 53 & .031 \\
\hline Pantalone (pants) & $\begin{array}{l}\text { Exp. } 2 \text { contr. gr. } \\
\text { Exp. } 1 \text { contr. gr. }\end{array}$ & $\begin{array}{l}714.66 \\
553.10\end{array}$ & $\begin{array}{l}153.28 \\
113.35\end{array}$ & 4.08 & 51 & $<.001$ \\
\hline Stan (apartment) & $\begin{array}{l}\text { Exp. } 2 \text { contr. gr. } \\
\text { Exp. } 1 \text { contr. gr. }\end{array}$ & $\begin{array}{l}759.06 \\
567.09\end{array}$ & $\begin{array}{l}315.61 \\
155.87\end{array}$ & 2.59 & 52 & .013 \\
\hline Kuća (house) & $\begin{array}{l}\text { Exp. } 2 \text { contr. gr. } \\
\text { Exp. } 1 \text { contr. gr. }\end{array}$ & $\begin{array}{l}699.18 \\
564.04\end{array}$ & $\begin{array}{l}207.91 \\
105.75\end{array}$ & 2.81 & 53 & .007 \\
\hline Koliba (hut) & $\begin{array}{l}\text { Exp. } 2 \text { contr. gr. } \\
\text { Exp. } 1 \text { contr. gr. }\end{array}$ & $\begin{array}{l}793.30 \\
613.27\end{array}$ & $\begin{array}{l}297.21 \\
167.90\end{array}$ & 2.58 & 53 & .013 \\
\hline Vikendica (cottage) & $\begin{array}{l}\text { Exp. } 2 \text { contr. gr. } \\
\text { Exp. } 1 \text { contr. gr. }\end{array}$ & $\begin{array}{l}772.12 \\
633.52 \\
\end{array}$ & $\begin{array}{r}203.77 \\
98.42 \\
\end{array}$ & 3.34 & 52 & .002 \\
\hline
\end{tabular}

\subsection{Discussion}

Additional comparisons of mean RTs for filler items in experimental and control groups from Experiments 1 and 2 showed significantly higher RTs recorded in the second experiment. Both experimental groups from the two experiments were exposed to similar procedures which involved initial priming and a subsequent RT study. The only difference was the nature of the main task: Experiment 1 involved a lexical decision task while 
Experiment 2 involved a categorization task. Consequently, the differences in RTs recorded in this section can be attributed to the nature of the task. Significantly faster RTs recorded in the first experiment show that the lexical decision task involves reduced cognitive load which overrides the priming condition, while slower RTs recorded in Experiment 2 suggest that categorization presents a more demanding task. This in turn also shows that the categorization task is more suitable for the detection of semantic frame activation through linguistic priming in an RT paradigm.

A similar tendency recorded in the two control groups is an even more obvious indicator of the differences in the difficulties of the main tasks in Experiments 1 and 2. Namely, control groups did not undergo any priming, but proceeded directly to the main task, under identical conditions. Therefore, the significantly slower RTs recorded in the second experiment again attest to the higher degree of difficulty attributable to the categorization task. In conclusion, the results obtained in this section offer important methodological implications for the design of future studies, since the lexical decision task clearly is not a suitable procedure for the detection of semantic frame activation via lexical priming in an RT paradigm.

\section{GENERAL DISCUSSION}

Experiments 1 and 2 were designed to test the activation of semantic frames of JOURNEY and CONFLICT, respectively, via semantic pre-task priming. After the priming procedure, the experimental group in Experiment 1 proceeded to the lexical decision task presented in an RT paradigm, whereas the experimental group in Experiment 2 proceeded to the categorization task, also in an RT paradigm. The expected facilitation in the experimental group in Experiment 1 did not occur; furthermore, the control group in this experiment showed faster RTs to most of the targets. In Experiment 2, on the other hand, the experimental group showed consistently faster RTs for the majority of target stimuli. The comparison of overall mean tendencies between the experimental and control group in Experiment 2 yielded significance, with faster RTs in the experimental group.

The comparisons of mean RTs for filler items between experimental and control groups from Experiments 1 and 2 showed significantly faster RTs recorded in the first experiment. Based on the discussion already outlined above, we concluded that the lexical decision task is not a suitable approach to test the semantic frame activation in our experimental setup. Such findings support the hypothesis that the lexical decision task reduces the cognitive load, thereby overriding the priming condition.

Although the categorization task presents itself as a more favorable approach for the exploration of semantic frame activation through linguistic priming in an RT paradigm, there is an additional issue which needs to be addressed. Namely, it remains unclear whether the inhibition recorded in the experimental group in the first experiment can be, at least in part, attributed to the highly entrenched nature of the JOURNEY frame. The results from Experiment 2 show a clear activation of the CONFLICT frame via appropriate semantic material; however, one could just as easily argue that the frame of CONFLICT is also highly entrenched, and very frequent both in its literal and metaphorical use. This argument raises an obvious question of whether the level of entrenchment has had any significant effect on the obtained results in the first experiment. An additional experiment similar to the design of the first experiment, and with the same set of stimuli from the first experiment, but based 
on the categorization task would offer clear insight into whether the results in Experiment 1 were biased by the nature of the main task, or also by some additional covert factors, such as the level of frame entrenchment. However, this particular point remains to be addressed in future research.

\section{CONCLUSIONS AND SUGGESTIONS FOR FUTURE RESEARCH}

Based on the results outlined above it can be concluded that the categorization task presents itself as a more favorable approach for testing semantic frame activation in an RT paradigm compared to the lexical decision task. Most likely, this is due to the reduced cognitive load associated with the latter task, as evidenced in the two experiments. In effect, future research should benefit from this finding and explore further the possibilities of testing semantic frame activation through categorization tasks. One obvious direction for future research should include online priming procedures, rather than pre-task priming. Namely, the more dynamic online priming should facilitate stronger and more stable activation of target frames, so that the activation level is preserved over longer periods of time. Another important direction of research could include testing the level of frame activation in participants' second language, which could, in turn, offer valuable insights into the mechanisms of categorization and the organization of knowledge in their second language, with possible implications for foreign language teaching.

\section{APPENDIX A}

I arrived in Prague by train which had departed from Belgrade yesterday, and went in search for an accommodation. First, I inquired in the nearby hotels located around the railway station, which were very close to one another, and in which I had always stayed during my previous visits. However, I could not get a room, since, as I was told, everything had been booked, so I was forced to dive further into the city, and inquire at other addresses that I had been given by porters after they denied me lodgings.

It was November, and due to the immense cold, I would shiver every time I went out into the street to get to the next hotel, but I also forced myself to proceed with the search aware that if I didn't find a place to spend the night, I would be forced to stay in the train station hall.

To distract myself from thinking about the cold, I remembered the journey and all other sights that I had witnessed from the window of the train that was gliding smoothly along the rail tracks: winding country roads, crossroads, bridges with people, trucks, and cars, some of which were crawling, others rushing, everyone about their business. Everything was in perpetual motion, like me now, while I was wandering along the unfamiliar city streets in search of any kind of shelter.

\section{APPENDIX B}

Philip II, the father of Alexander the Great, possessed an exceptional gift for military affairs and for governing the state, so it was not difficult for him to conduct a reform of the political and military system of his country. From a feudal state with a clan system, he created a powerful force ruled by one man and which had a well-trained and well-equipped army.

Indeed, Filip paid the greatest attention to the organization and tactical training of the Macedonian army. He then used his supremacy to unite everyone under his rule in order to create a large enough army that he hoped would enable him to defeat his great enemy - Persia. 
Philip created the phalanx, a detachment of infantry armed with spears about five meters long, and whose striking power had no match in the world at that time. A special part of the infantry consisted of squires, more easily armed than phalanxes, so they had a different role in battle. Apart from them, an indispensable part of the army was the Macedonian cavalry, which was very powerful and consisted of noblemen armed with spears and swords, and there was also another part of cavalry - spearmen. Philip's army also included archers, lightly armed infantry and a large number of Greek mercenaries.

\section{REFERENCES}

Barsalou, Lawrence W. 1983. “Ad hoc categories.” Memory \& Cognition 11, no. 3: 211-227.

Croft, William and Allan D. Cruse. 2004. Cognitive Linguistics. Cambridge: Cambridge University Press.

Evans, Vyvyan. 2009. How Words Mean: Lexical Concepts, Cognitive Models, and Meaning Construction. Oxford: Oxford University Press.

Evans, Vyvyan and Melanie Green. 2006. Cognitive Linguistics: An Introduction. Edinburgh: Edinburgh University Press.

Fillmore, Charles J. 1969. "Verbs of judging: An exercise in semantic description.” Papers in Linguistics 1, no.1: 91-117.

Fillmore, Charles J. 1975. “An Alternative to Checklist Theories of Meaning.” Proceedings of the First Annual Meeting of the Berkeley Linguistics Society: 123-131.

Fillmore, Charles J. 1976. "Frame Semantics and the Nature of Language." Annals of the New York Academy of Sciences, Origins and Evolution of Language and Speech 280, no. 1: 20-32.

Fillmore, Charles J. 1982. "Frame Semantics." In Linguistics in the Morning Calm, edited by The Linguistic Society of Korea: 111-137.

Fillmore, Charles J. 1985. "Frames and the Semantics of Understanding." Quaderni Di Semantica VI, no. 2: $222-254$.

Fillmore, Charles J. and Beryl T. Atkins. 1992. "Towards a Frame-Based Lexicon: The Semantics of RISK and its Neighbors." In Frames, Fields, and Contrasts, edited by Adrienne Lehrer and Eva F. Kittay: 75-102. Hillsdale / Hove / London: Lawrence Erlbaum Associates Publishers.

Higgins, Tory E., John A. Bargh, and Wendy Lombardi. 1985. "Nature of Priming Effects on Categorization." Journal of Experimental Psychology: Learning, Memory, and Cognition 11, no. 1: 59-69.

Kostić, Aleksandar. 2010. Kognitivna psihologija. Beograd: Zavod za udžbenike i nastavna sredstva.

Lakoff, George. 1973. "Hedges: A Study in Meaning Criteria and the Logic of Fuzzy Concepts." Journal of Philosophical Logic, no. 2: 458-508.

Lakoff, George. 1987. Women, Fire, and Dangerous Things: What Categories Reveal about the Mind. Chicago and London: The University of Chicago Press.

Mathôt, Sebastiaan, Daniel Schreij, and Jan Theeuwes. 2012. "OpenSesame: An open-source, graphical experiment builder for the social sciences." Behavior Research Methods 44, no. 2: 314-324.

McNamara, Timothy P. 1994. "Theories of Priming: II. Types of Primes." Journal of Experimental Psychology: Learning, Memory, and Cognition 20, no. 3: 507-520.

McNamara, Timothy P. 2005. Semantic priming: Perspectives from memory and word recognition. New York and Hove: Psychology Press.

McNamara, Timothy P. and Vaibhav A. Diwadkar. 1996. "The Context of Memory Retrieval." Journal of Memory and Language, no. 35: 877-892.

Meyer, David E. and Gwendolyn B. Ellis. 1970. "Parallel Processes in Word Recognition." Paper presented at the annual Psychonomic Society Meeting in San Antonio, Texas, on November 5-7, 1970.

Meyer, David E. and Roger W. Schvaneveldt. 1971. "Facilitation in recognizing pairs of words: Evidence of a dependence between retrieval operations." Journal of Experimental Psychology 90, no. 2: 227-234.

Rosch, Eleanor. 1973. "Natural Categories.” Cognitive Psychology, no. 4: 328-350.

Rosch, Eleanor. 1975. "Cognitive Representations of Semantic Categories.” Journal of Experimental Psychology: General 104, no. 3: 192-233.

Rosch, Eleanor and Carolyn B. Mervis. 1975. "Family Resemblances: Studies in the Internal Structure of Categories." Cognitive Psychology, no. 7: 573-605.

Rosch, Eleanor, Carolyn B. Mervis, Wayne D. Gray, David M. Johnson, and Penny Boyes-Braem. 1976. "Basic Objects in Natural Categories." Cognitive Psychology, no. 8: 382-439.

Taylor, John R. 1995. Linguistic Categorization: Prototypes in Linguistic Theory, $2^{\text {nd }}$ edition. Oxford: Clarendon Press. Wittgenstein, Ludwig. 1958. Philosophical Investigations. Translated by Gertrude Elizabeth Margaret Anscombe. Oxford: Basil Blackwell.

Zadeh, Lotfi A. 1965. "Fuzzy Sets." Information and Control, no. 8: 338-353. 


\section{ISPITIVANJE AKTIVACIJE SEMANTIČKIH OKVIRA U ZADATKU LEKSIČKE ODLUKE I ZADATKU KATEGORIZACIJE}

Istraživanje smo sproveli u teorijskom okviru semantike okvira (Fillmore 1982) i koristimo eksperimentalni pristup zasnovan na merenju vremena reakcije kako bismo ispitali uticaj primovanja na aktivaciju semantičkih okvira. U prvom eksperimentu testirali smo okvir PUTOVANJA, kroz merenje vremena reakcije u zadatku leksičke odluke. U drugom eksperimentu testirali smo okvir KONFLIKTA, kroz merenje vremena reakcije u zadatku kategorizacije. Glavni stumulusi odabrani su kroz postupak normiranja prema stepenu prototipičnosti na Likertovim skalama, a pored njih korišćeni su $i$, fileri “. Primovanje je sprovedeno upotrebom semantičkog materijala modifikovanog kako bi doveo do aktivacije svakog od dva ciljna okvirna. Rezultati nisu pokazali očekivanu aktivaciju u eksperimentalnoj grupi u prvom eksperimentu, u odnosu na kontrolnu grupu, dok je u drugom eksperimentu zabeležena očekivana aktivacija. Ovo ukazuje da je zadatak leksičke odluke kognitivno lakši u poređenju sa zadatkom kategorizacije, zahvaljujući čemu u zadatku leksičke odluke dolazi do premošćavanja efekta primovanja. Prema tome, zadatak kategorizacije predstavlja pouzdaniju proceduru za testiranje aktivacije semantičkih okvira.

Ključne reči: semantički okvir, leksička odluka, kategorizacija, vreme reakcije, primovanje, Open Sesame. 